\title{
Factors, Observed during Covid-19, to Overcome Financial Crisis: a Case of Bangladesh
}

\author{
Ashraf Uddin, Md. Manzurul Hasan, Md. Siyamul Islam and Md. Mehedi Hassan Onik
}

\begin{abstract}
Covid-19 has furiously affected the world economy. Despite the world's suffering, Bangladesh has shown a new model of surviving from devastating financial crisis. There are several factors, rarely observed during the pre-pandemic period, helped Bangladesh to stand up adopting the new normal. We have identified that the factors were not directly the results of Government policies, but the necessity people had to change to live the new normal. In this paper, several directions of financial activities and sectors have been explored with evidence and insights in the context of Bangladesh.
\end{abstract}

Index Terms - Bangladesh, Creative Economy, Covid-19, Financial Crisis

\section{INTRODUCTION}

Bangladesh has recently been recommended to become a developing country by 2026. Covd-19 epidemic and the downward graph of world economy could not be an obstacle in the goal. The partial lockdown, enforced from the last year, which is still active to some extent throughout the country, could not stop financial activities. Thus, study is aimed to look at the factors which helped to overcome and moving the economy in the pandemic time. In the following sections, we focus on different significant financial factors, policies and changing behavior of people in the daily life.

\section{INCREASING REMITTANCE}

Millions of Bangladesh citizen have migrated to abroad in search of a living. This migration trend has been directly affected by the remittance of Bangladesh [1]. A significant portion of the total GDP of Bangladesh (around 15\%), is contributed from remittance [2]. Low labor cost, availability, efficiency, adaptability and low life expectancy etc. are the driving force for the huge demand of Bangladesh workers in foreign countries. Besides, students, defense officers, IT experts also contribute a lot to bring remittance.

Ashraf Uddin is with the American International University-Bangladesh (email: dr.ashraf@aiub.edu).

Md. Manzurul Hasan is with the American International UniversityBangladesh (email: manzurul@aiub.edu).

Md. Siyamul Islam is with the American International UniversityBangladesh (email: siyamul@aiub.edu).

Md. Mehedi Hassan Onik is with the American International UniversityBangladesh (email: mehedi.onik@aiub.edu).
Increasing remittance trends have been noticed during the last decade but the amount increased in many folds during the Covid-19 outbreak. People are investing more money in digital platforms these days. In 2020-2021 fiscal year, wage earner's remittance has increased drastically as shown in Table 1.

TABLE I

YEARLY DATA OF WAGE EARNER'S REMITTANCE FROM THE FISCAL YEAR 2010-11 TO 2020-21 [7]

\begin{tabular}{|c|c|c|}
\hline \multirow{2}{*}{ Year/Month } & \multicolumn{2}{|c|}{ Remittances } \\
\cline { 2 - 3 } & In million USD & In billion Taka \\
\hline $2020-2021 *$ & 14907.35 & 1264.27 \\
\hline $2019-2020$ & 18205.01 & 1543.52 \\
\hline $2018-2019$ & 16419.63 & 1380.07 \\
\hline $2017-2018$ & 14981.69 & 1231.56 \\
\hline $2016-2017$ & 12769.45 & 1010.99 \\
\hline $2015-2016$ & 14931.18 & 1168.57 \\
\hline $2014-2015$ & 15316.91 & 1189.93 \\
\hline $2013-2014$ & 14228.26 & 1105.84 \\
\hline $2012-2013$ & 14461.14 & 1156.47 \\
\hline $2011-2012$ & 12843.43 & 1018.82 \\
\hline $2010-2011$ & 11650.32 & 829.91 \\
\hline
\end{tabular}

*The data is for till the month of January for financial year 2020-2021.

Previously, most of that money used to come via the illegal intermediates. After introducing cash incentive for incoming remittance, the government started to receive more remittance through legal ways. Since the country is embracing a digital version of itself, banking sectors along with the financial transaction has become more sustainable and secure. This means, more remittances are being sent and received via a digital medium like online banking, mobile banking, agent banking, online fund transfer etc. The government is promoting digital payment, reducing transaction cost, creating more money withdrawal point and introducing new techpolicy to increase the foreign reserve of Bangladesh [3-6].

During covid-19 period, alike the whole world, Bangladesh 
is also experiencing a tough time. Remittance money came as a blessing, government as well as individuals are investing the remittance money to uphold the poor economy amidst the pandemic. The government could not have provided 11.90 billion USD stimulus packages during Covid-19 without the contribution of growing remittance [8-9].

Needless to say, the remittance industry is growing rapidly with the aid of advanced technologies. Arrival and availability of Internet [11], the emergence of mobile finance [12], money transfer business [13] and promoting digital payment by Bangladesh government are encouraging mass people to utilize the secure and easily accessible digital remittance related technologies by providing instant incentive, lowering internet price, making it available everywhere, lessening policies and regulations etc. [14].

\section{NEW PROSPECTS OF INVESTMENT}

One of the tendencies is to invest money on buying gold, real state or share market in this pandemic [15-16]. People are relying less on the bank rather than investing the money in the aforementioned sectors.

People can now easily download an Application to monitor their share market activities [17]. Another important factor is the availability of information. Nowadays, even remote people can know what is happening in the world through the internet and television. People watch share market experts' suggestive videos on YouTube to make a critical decision [18]. Now, many people newly started these as they have more time to do so.

Although it is not legal but Bangladesh people are also investing in international foreign exchange (similar to share market) too. Forex business is based on technology and can run with a smartphone. E-Trading is exponentially raising the accessibility of data, giving clients access to more data about the value and other critical share market-related issues. Finally, the main factors that are actively increasing the gold, stock and share market industry in Bangladesh are data analytics supported brokers, digital stock market, real time scrutinizing and fast transaction [19-22].

\section{GROWTH OF E-GovernancE}

In pre-pandemic time, citizens used to get a loan from bank or government organization in person. However, during this pandemic restriction has been imposed on outside movements. To maintain a good economy government builds websites, applications, advertisements etc. Taxpayers could easily file their tax, farmers could easily get govt. loans, students could easily get student loans, small entrepreneurs could get govt. loans; and everything was distributed and managed digitally [23].

Besides, Government officials meeting, inauguration, closing ceremony, convocation, voting, budget discussion, national addressing etc. are managed and organized via online communication platform. Electronic voting has become a great means to control corruption and as well as a social gathering in Bangladesh [24]. Daily covid-19 reports, the directions from Government and cabinet meeting everything is being done here in Bangladesh with online platform [25]. So, this is one of the major changes during the Covid-19.

\section{AdOPTING TECHNOLOGY DRIVEN ECONOMY}

Though Covid-19 did a massive destruction not only in Bangladesh but also all over the world, but if we compare the development of Bangladesh with respect to the vulnerable effects due to Covid-19 then one can easily observe that Bangladesh is in far better position in the growth of economy than that of most of the countries in the world [26]. Some parameters been discussed below.

Bangladesh government was forced to give central lock down from 17 March 2020 to 30 May 2020 [27]. Almost all offices, industries got shut down. But to keep the payment to the workers, garments owners made took the support of bKash, Rocket and ATM card facilities [28]. Whereas, in most of the countries, banking service is only for the elite people but in Bangladesh most of the citizens can make accounts with the minimum deposit and after opening an account they can have ATM cards. Account opening procedures are so simple in Bangladesh. They can easily open mobile banking account with the minimum use of time, just with a valid NID [29]. SMS services are regularly activated against banking services. When consecutive lockdown hampers the owners to make payments to workers, the owners were bound to cut salary within a threshold level, the poor became bound to go outside as a survival of the fittest.

\section{RMG sector}

In the modern days Ready Made Garments (RMG) and their associated industries like accessories are the key turbines of Bangladesh economy, even sometimes is superior to the agriculture sector.

Then government took some initiatives to open garment industries partially in roster basis maintaining safe distances and in hygienic environments. The workers were regularly informed by messages over mobile phones about the schedule. They were cleaned before entering the work premises through a sanitized tunnel. Many garment industries set up pipelines to wash hands of the workers before entering the industries. Though the markets were closed, people did shop over mcommerce, e-commerce, and f-commerce. That keeps the local market of RMG is at warming situation. Merchants did delivery at home and took payments over various online and mobile platforms just to avoid physical transactions. Different exporters and importers related to RMG took banking facilities over Email. Letter of Credit (LC) over SWIFT (Society for Worldwide Interbank Financial Telecommunication) help us regularly a lot in export and import. Buying Houses, Fashion Designers, Merchandisers did home offices using internet as well as using different software and tools. Recently, positive news has been published that, despite Corona outbreak, one of the most famous sites Alibaba's trade has been boost up at B2B because of technology [34-35].

Pharmaceutical Sector 
Pharmaceutical companies play a great role in Bangladesh economy. But during central lockdown the industries maintain home offices by using internet. Almost all the major companies in Bangladesh like Square, Incepta, Beximco, ACI, Drug International etc. (limited companies) use ERP solution [31-33]. So, it became a little bit easier for the corporates to maintain their offices. Besides, at the local market, medicine shops most often took orders over short messages and the merchants made home delivery. It is almost a common belief that a good number of people from rich to poor are under internet coverage that is very higher than that of the previous year's [30].

To overcome the covid-19 pandemic situation and its post facto effects, many tools, equipment, and their managements become essential. In this regard by scrolling different solution techniques over internet people open their businesses and services in small, medium and enterprise form. Since people are staying at home and are doing all the necessary works virtually all the cost regarding import, export low. Production cost and service cost are becoming cheaper. A good reflection is being seen over the situation.

\section{ADOPTING NEW NORMAL}

To survive in the society people came to know how to adopt with the pandemic, especially to earn livings. They go outside but they maintain proper healthy measures. People came to know that they have to expense more to procure electronic services than that of basic needs. People got expert in online systems and services. They became habituated in electronic transactions, they got e banking services. Since they get e banking services, they come to know that they have to save money, deposit money in fruitful sectors. Banking facilities always accelerates in saving tendency. Not only banks but also almost all deposit schemes have come in soft form like Sancaypatra, different deposit schemes at different financial organizations, Treasury market, Stock exchanges and exchanges houses. Virtual money flow has been increased in the market that minimizes the liquid money and increases money in the capital market. This is a good symptom. Many markets come in the market as startups to invest with different attractive schemes, do marketing to attract the mass people and development is being seen as a continuous process.

\section{Stimulating PACKAGES AND INCENTIVES}

Going to work throughout this COVID-19 pandemic has placed frontline staffs such as doctors, nurse, bankers, law enforcement forces under massive and unprecedented pressure. At the same time, their physical and mental health along with life is at risk. Due to extreme stress, for prolonged periods may results in with several harmful consequences on the mental and emotional health of frontline staffs. So for encouraging the frontline workers Bangladesh government has adopted various special offers. It's been decided to supply financial help as compensation if any doctors, nurses and physicians operating to supply services to patients. Same decision is taken for field administrators, defense forces, law enforcement forces and alternative staffs operating to make sure the implementation of government mandates, get infected with Novel Coronavirus. Govt. officers and employees are going to be provided 50-10 lakhs Bangladeshi monetary unit in keeping with grade. And if anyone dies, they're going to get five times additional money help [36].

According to the 2015 earnings scale, if somebody within the 15-30th grade is infected, can get compensation of five lakhs Bangladeshi monetary unit, and if he dies, he can get twenty-five lakhs Bangladeshi monetary unit. If somebody of 10th-14th grade is infected, he can get seven.5 lakhs Bangladeshi monetary unit and if he dies, he can get thirtyseven lakhs Bangladeshi monetary unit. Besides, if somebody of first-ninth grade is infected, he can get ten lakhs Bangladeshi monetary unit and if he dies, he can get fifty lakhs Bangladeshi monetary unit shown in the figure 1.

The notice more states that doctors, nurses, physicians, field directors, enforcement officers, soldiers and alternative personnel directly concerned to supply services to patients infected with coronavirus and to implement government directions are going to be thought of underneath this instruction.[37]

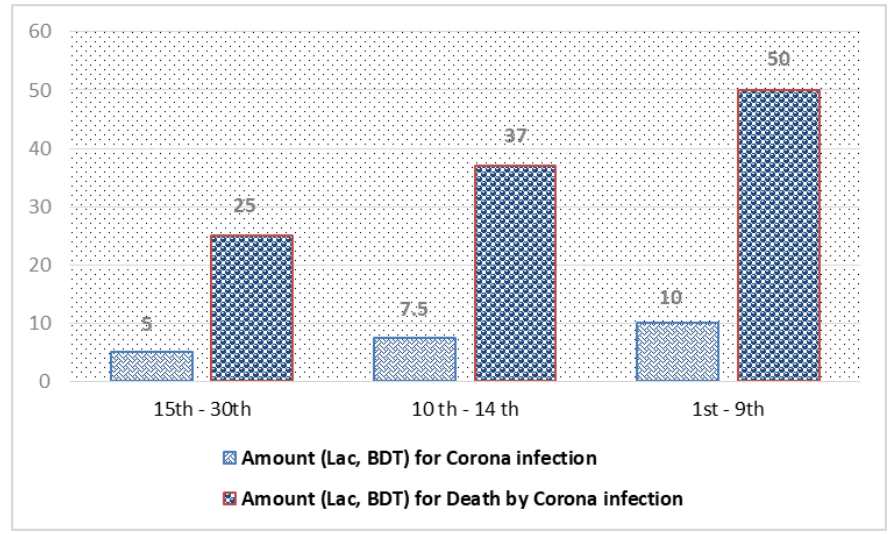

Fig. 1. Compensation amount given by Bangladesh Govt. to different grades of employees.

The government has up to now proclaimed a collection of stimulant packages value a near of 12 billion US dollar equivalent to 1.011 trillion taka) to offset the COVID-19 shock on numerous sectors of the country and minimize the sufferings of the folks hit exhausting by the nationwide closing implemented to deflect the deadly virus [8].

Total 18 economic sectors are taken under incentive declared packages. These sectors consist of export-oriented industries, agricultural industries i.e., livestock, poultry, and fish culture along with small, cottage and medium industries. The highest 300 billion taka has been sanctioned for affected industries among the packages and second highest amount of 200 billion taka is assigned for small, medium and cottage enterprises to supply working capital.

The government declared other incentive packages worth of Taka 50 billion specially for the export-focusing industries addition with approximate taka 128 billion Export Development Fund (EDF) by Bangladesh Bank to enlarge the facilities. Besides, the government declared taka 1 billion as special offer for the frontline workers like doctors, nurses, national security forces to encourage their dedication, taka 
7.50 billion for life and health insurance for govt. employees, and taka 25.03 billion for distributing food materials to the low-income people.

The rest of the facilitation bundles proclaimed by the government are agriculture appropriation with 95 billion taka, farming renegotiating conspire with 50 billion taka, renegotiating plot for the low-income cultivators and Inappreciable businessmen with thirty billion, rice encasing per kilo 10 worth of taka 2.51 billion, and give out the cash among to the target-based communities in amount of taka 12.58 billion.

In addition, stimulating bundles for extending the scope of rationing program with Taka 8.15 billion, house installation for homeless people with Taka 21.30 billion, extra 2 lakhs metric tons Boro rice buying scheme with Taka 8.60 billion, and mechanization of horticulture works with Taka 2 billion were proclaimed since the outbreak period of the coronavirus.

On 14 May, the Prime Minister of Bangladesh launched the dispensing of 12.50 billion Taka help among 5 million needed families during the pandemic situation of COVID-19. By this program, each of these poor badly affected families by COVID-19 pandemic situation are helped with Taka 2,500 at the end of the Ramadan end eve of the Eid through mobile financial services (MFSs).

Total 25 billion Taka was assigned to Probsahi Kalyan Bank, Palli Sanchay Bank, and Palli Karma Sahayak Foundation to support the young people and expatriates who lost their employments during the Covid-19 period.

\section{SAVING TENDENCY}

Covid-19 virus has affected many folks worldwide. Not solely it has caused a large health crisis; it's conjointly let the world economy in an exceedingly wounded state. Worldwide forced lockdown though a welcome action to cut back the propagation of Covid-19, it has left the common people in an exceedingly grim condition where most of the jobs and businesses have suffered a lot. Therefore, saving and investment have emerged as foundation of our economy by which the national economy will survive in this pandemic. Saving is a far-reaching habit which has helped us in the past to face international economic crises. When Covid-19 has halted the incomes, it has made them recognize the importance of a little sum of cash saved up for a hard time. Few preferred investment choices are suggested to mobilize the daily life during the pandemic like Covid-19 [42] which are discussed below:

\section{Life Insurance}

Covid-19 has displayed the life as absolute uncertainty. The extremity of families reached at high pick without the earning members, and it isn't hidden from anyone. As a way to safeguard the family's future, the people are going for life insurance day by day.

\section{Systematic Investment Plans (SIPs)}

Nowadays investors are adopting SIPs as a popular investment technique. However, Covid-19 pandemic yielded SIPs with more importance. Once the tiny monthly savings within the approach of SIPs helped people in supporting these misfortunes, it steered to additional people implementing SIPs as a life scheme.

\section{Fixed Deposits}

Once the whole economy was fallen at its feet, the only real issue that supplied slightly relief was the amount of money that was kept as fixed deposits in banks. It had been safe, merely retrievable and accommodated to any or all short wishes of people. Many people adopted only the fixed deposits to tackle this hard time while everything else were unsuccessful.

\section{NEW STARTUPS}

Covid-19 has been a reason of suffering for Bangladesh's startups. The unordinary health crisis and inactivity led to downing of many startups such as travel, tourism and hospitality, and electronics. However, there are some blissful things happened at the other side.

Startups operating in grocery, essential services, ride sharing and medicine have grown very fast. Healthcare, digitallearning, logistics and financial technology services flourished on rolling demand. Ride sharing has been used to avoid public transport. Many parcel services started for delivery at doors, contactless payment. Dhaka Cast, Co-Space and Upskill are three evident examples of successful startups in the pandemic.

With the lockdown coming into effect at the end of March 2020, "Dhaka Cast" which is an online healthcare consultancy provider for diabetics got a boost in the following months. Similarly, CoSpace, an office space solution provider observed a boost. Homegrown and popular ride-sharing service Pathao began delivering medicine and groceries in May as lockdowns restricted public movement. Some 7 per cent witnessed an increase in business [38].

Bangladesh registered incredible growth in the startup ecosystem recently. Today, there are 1,000-plus startups in the country and these have secured over \$260 million in investments, mostly from global investors, as reported by LightCastle. Startups have created 15 lakh direct and indirect jobs over the recent years including among rideshare service providers and bicycle-riding delivery persons [39].

\section{MiscellaneOUs}

\section{Education}

To talk about research, many publishers and universities made their repositories open to download a very good number of papers without any cost during lock-down, even still now [4041]. Since most of the universities are still operating their academic works over online like Zoom, MS Teams etc., the intellectual communities are staying at home. The scholars are concentrating their minds in research than that of before. It has been contributing directly or indirectly in commercial markets as well as in the financial markets. It is obviously worthy to mention that outcome from any scientific paper like physical science and biological science can never be metered in the scale of money. Outcome of vaccine is also from the works of intellectuals. 


\section{ICT for ICT}

It has been observed that all are becoming virtual with the taste of virtual reality. It is a common belief that even if novel Corona virus leaves us permanently, but virtual activity will consistently leads the market. People have learnt how to come out from rent of offices, living at rural areas but to do offices in urban areas. In this issue, communication channels and its associated tools, techniques and security are the key factors to be globally local. So, software will be needed for software to $\log$. Security tools along at different spans like software and hardware security will be needed more to create obstacles against hackers and crackers. Randomization is working under random numbers; algorithms are becoming online-algorithms. Software companies are getting busy with their upgraded versions of all the software. New solutions are needed not only in software engineering but also in computer networks and communications system with the fastest and smartest forms. So Covid-19 not only hits us but also teaches how to survive in the twenty first century at the age of AI, IOT, Big-Data, Data Science and Machine learning.

\section{CONCLUSION}

The paper discussed several dimensions of financial activities which retained the economy to overcome the unprecedented situation due to Covid-19. There might be many other issues which could be discussed as well. We aimed to cover the issues only in the context of Bangladesh. Similar may be observed in some other countries as well. This study will help to find points to figure out such problems in future in better ways. As we tried to capture only positive things adopted by people but there are some things in the other side also like losing job due to financial deficiency. This iterates the necessity of building emergency fund in the private organizations so that the fund can be used later in the economic crisis.

\section{REFERENCES}

[1] https://www.xpressmoney.com/blog/authors/the-burgeoning-southasian-remittance-industry/, Latest Access on $4^{\text {th }}$ March 2021.

[2]S. A. Rahim, and M.A. Alam, "Foreign remittance income in Bangladesh: Opportunities and challenges," Asian Business Review, vol. 2, no. 2, pp. 8086, 2013.

[3]M. S. Islam, and S. Nasrin, "Driving forces of remittance inflow in Bangladesh: An empirical study," International Journal of Economics and Finance, vol. 7, no. 6, pp. 126-138, 2015.

[4] M.S. Islam, "An Econometric Analysis on Remittance and Economic Growth in Bangladesh," International Journal of Economics and Financial Research, vol. 6, no. 10, pp. 214-218, 2020.

[5] M. Moniruzzaman, "The Impact of remittances on household food security: Evidence from a survey in Bangladesh," Migration and Development, pp. 1-20, 2020.

[6] https://www.xpressmoney.com/blog/whats-new/cash-incentive-forbangladesh-expats/, Latest Access on $4^{\text {th }}$ March 2021.

[7] https://www.bb.org.bd/econdata/wageremitance.php\#, Latest Access on $4^{\text {th }}$ March 2021.

[8] https://thefinancialexpress.com.bd/economy/bangladesh/covid-19-govtso-far-announces-1190b-stimulus-packages-1590759538, Latest Access on $4^{\text {th }}$ March 2021.

[9] https://www.thedailystar.net/supplements/news/digital-bangladesh2021-payment-systems-and-fintech-1974417, Latest Access on $4^{\text {th }}$ March 2021.

[10] https://www.bb.org.bd/econdata/intreserve.php, Latest Access on $4^{\text {th }}$ March 2021
[11] http://www.xinhuanet.com/english/2021-02/03/c 139719107.htm, Latest Access on $4^{\text {th }}$ March 2021.

[12] M.S. Islam, N. Karia, M.S.M. Soliman, M.H. Fouji, J. Khalid, and M. Khaleel, "Adoption of mobile banking in Bangladesh: a conceptual framework," Review of Social Sciences, vol. 2, no. 8, pp. 01-08, 2017.

[13] S. Yesmin, T.A. Paul, and M.M. Uddin,, "bKash: Revolutionizing mobile financial services in Bangladesh?" In Business and Management Practices in South Asia, pp. 125-148, Palgrave Macmillan, Singapore., 2019.

[14] https://www.worldremit.com/en/bangladesh-cash-incentive, Latest access on $4^{\text {th }}$ March 2021.

[15] https://www.dhakatribune.com/business/2020/08/09/why-is-gold-

becoming-more-expensive, Latest access on $4^{\text {th }}$ March 2021.

[16] https://www.ecosoftbd.com/online-share-trading/, Latest access on $4^{\text {th }}$ March 2021.

[17]

https://mof.portal.gov.bd/sites/default/files/files/mof.portal.gov.bd/page/ed9e8 b19_ccba 4cca_94b1_c40013f7a760/MTMPS 2020-21_English.pdf, Latest access on $4^{\text {th }}$ March 2021.

[18] C. Das, "Significant Issues of financial literacy and application in stock market: A descriptive study on Bangladesh capital market," International Journal of Business Society, vol.3, no. 1, pp. 38-44, 2019.

[19] S. M. Hoque, and S.M. Alam, "E-trading and Stock Market in Bangladesh: Problems, Prospects and Way Forward," The Accountant (Bangladesh), 2010.

[20] https://www.finsmes.com/2020/06/how-technology-influences-thestock-trading-market.html, Latest access on $4^{\text {th }}$ March 2021.

[21] https://finance.zacks.com/impact-technology-stock-market-5807.html, Latest access on $4^{\text {th }}$ March 2021.

[22] M.A. Ashraf, and H.R. Joarder, "The Effect of Information Technology on Stock Market Trade Volume and Volatility: Case for Dhaka Stock Exchange in Bangladesh," AU JT, vol. 12, no. 4, pp. 265-270, 2009.

[23] https://www.aa.com.tr/en/asia-pacific/bangladesh-to-give-phone-loansto-pupils-amid-lockdown/1971859, Latest access on $4^{\text {th }}$ March 2021.

[24] https://mof.gov.bd, Latest access on $4^{\text {th }}$ March 2021.

[25] M. Shammi, M. Bodrud-Doza, A.R.M.T. Islam, and M.M. Rahman, "Strategic assessment of COVID-19 pandemic in Bangladesh: comparative lockdown scenario analysis, public perception, and management for sustainability," Environment, Development and Sustainability, pp. 1-44, 2020. [26]

https://data.worldbank.org/indicator/NY.GDP.MKTP.KD.ZG?locations=B D, Latest access on $4^{\text {th }}$ March 2021.

[27] https://en.wikipedia.org/wiki/COVID-19_pandemic_in_Bangladesh, Latest access on $4^{\text {th }}$ March 2021.

[28] https://www.lightcastlebd.com/insights/2020/06/17/mobile-financialservices-acceleration-in-digital-transactions-amidst-covid-19, Latest access on $4^{\text {th }}$ March 2021.

[29] https://www.youtube.com/watch? $v=p 02 b y E V 2 n 3 E$, Latest access on $4^{\text {th }}$ March 2021.

[30] https://data.worldbank.org/indicator/IT.NET.USER.ZS?locations=BD, Latest access on $4^{\text {th }}$ March 2021.

[31] http://www.e-

home2u.com/software/SERVICES/ERP PharmaSIL.html, Latest access on $4^{\text {th }}$ March 2021.

[32] http://www.inceptapharma.com/our-growth.php, Latest access on $4^{\text {th }}$ March 2021.

[33]

https://www.beximcopharma.com/images/stories/investor/pdf/BPL AR 20 06.pdf, Latest access on $4^{\text {th }}$ March 2021.

[34] https://thefinancialexpress.com.bd/views/views/adaptability-oftechnology-digitisation-in-bangladeshs-rmg-sector-1609425899, Latest access on $4^{\text {th }}$ March 2021.

[35] https://www.thedailystar.net/opinion/news/what-technological-changesshould-the-rmg-sector-embrace-1967913, Latest access on $4^{\text {th }}$ March 2021.

[36] https://www.daily-bangladesh.com/english/Corona-infected-govtemployees-to-get-Tk-10-lakhs/41212, Latest access on $4^{\text {th }}$ March 2021.

[37] https://www.bb.org.bd/fnansys/paymentsys/mfsdata.php, Latest access on $4^{\text {th }}$ March 2021.

[38] https://www.thedailystar.net/business/news/startups-pandemic-daystale-despair-and-dreams-1957149, Latest access on $4^{\text {th }}$ March 2021.

[39] https://www.lightcastlebd.com/insights/2020/05/09/covid-19-impacton-the-startups-of-bangladesh, Latest access on $4^{\text {th }}$ March 2021.

[40] https://www.springernature.com/gp/researchers/thesource/blog/blogposts-life-in-research/access-textbooks-for-free-during-thecoronavirus-lockdown/17897628, Latest access on $4^{\text {th }}$ March 2021. 
[41] https://www.mcgill.ca/library/covid-19-open-resources, Latest access on $4^{\text {th }}$ March 2021.

[42] Dr. Reena Khanooja," Effect of covid-19 pandemic on saving and investment habits", International Journal of Current Research. Vol. 12, Issue, 11, pp.14660-14661, November, $2020 . \quad$ DOI: https://doi.org/10.24941/ijcr.40091.11.2020.

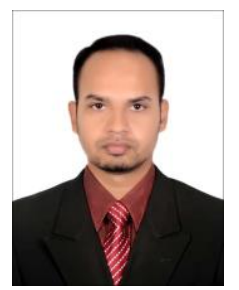

Ashraf Uddin received his B.Sc. from University of Dhaka. He received M.S. degree and $\mathrm{PhD}$ from the SAARC university, New Delhi, in 2013 and 2017, repectivevly.

Since 2018, he has been an Assistant Professor with the Computer Science Department, American International UniversityBangladesh. He is the author of more than 10 articles, and conference papers. His research interests include Data Mining, Sentiment Analysis and Natural Language Processing. Dr. Ashraf was a recipient of the SAARC jubilee scholarship from 2010 to 2016.

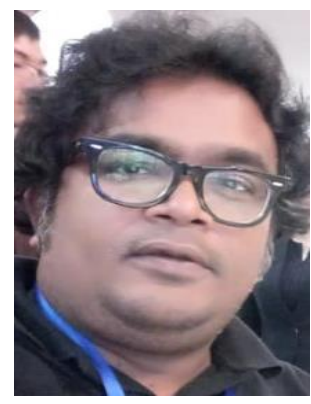

Md. Manzurul Hasan obtained his B. Sc. Engg. in Computer Science and Engineering (CSE) and M. Sc. Engg. in CSE from Chittagong University of Engineering \& Technology (CUET) and Bangladesh University of Engineering \& Technology (BUET) respectively. $\mathrm{He}$ is now a $\mathrm{Ph}$. $\mathrm{D}$. applicant from the department of CSE, BUET, Bangladesh.

Mr. Hasan is currently serving at the department of Computer Science as Assistant Professor in American International University-Bangladesh (AIUB). He served at different reputed professional organizations and at different teaching positions with a service length near about 16 years. He is an active member of different professional bodies like Institute of Engineers (IEB) and Bangladesh Computer Society etc. Depending on the research activity at his young age he was invited to attend the 12th HOPE Meeting with Nobel Laureates funded by JSPS, Japan. Mr. Hasan has a good number of prestigious publications in different journals and in different conference proceedings like Springer, ACM, IEEE xplore etc.

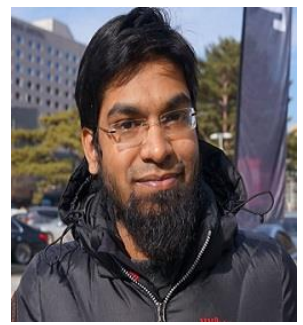

Md Siyamul Islam received his B.S degree in Computer Science and Engineering from Islamic University of Technology (IUT-OIC), Dhaka, Bangladesh in 2015 and the M.S. degree in Computer Science and Engineering from Kyung Hee University, Suwon, South Korea in 2019. He is currently working as a Lecturer in Dept. of Computer Science at American International UniversityBangladesh (AIUB), Dhaka, Bangladesh.

From 2017 to 2019 he was a Research Assistant with Data and Knowledge Engineering Laboratory, Kyung Hee University, Suwon, South Korea. His researche has been concentrated on
Big Data, Distributed Systems, Artificial Intelligence, Computer Vision and Machine Learning.

Mr. Md Siyamul Islam's awards and honors include President Scholarship, Brain Korea (BK21) Scholarship, Bangladesh Government Scholarship and Grameen Bank Award.

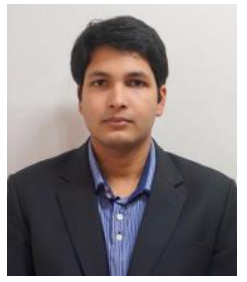

Md Mehedi Hassan Onik obtained his bachelor in Computer Science \& Engineering from the Islamic University of Technology, Bangladesh in 2014. He received his master's degree from Dept. of Computer Engineering, Inje University, South Korea in 2019. He is currently working as a lecture in the Department of Computer Science and Engineering at American International UniversityBangladesh (AIUB), Bangladesh. His research interests include usable privacy-security and blockchain technology. 